\title{
廃棄物埋立地から浸出する高濃度有機性廃液の 砂層中での挙動に関する実験的研究
}

\author{
中山正与 ${ }^{1} \cdot$ 江成敬次郎 $^{2}$
}

\author{
${ }^{1}$ 正会員 東北工業大学講師 工学部土木工学科（干982 宮城県仙台市太白区八木山香澄町 $35-1$ ) \\ ${ }^{2}$ 正会員 工博 東北工業大学教授 工学部土木工学科（干982 宮城県仙台市太白区八木山香澄町 35-1)
}

高濃度の有機性廃液が砂層中に浸透する場合の挙動について, 砂を $50 \mathrm{~cm}$ 厚さに充填したカラムを用いて 60 週にわたる実験を行い検討した．COD濃度が $24700 \mathrm{mg} / 1$ のカラム流入水は,砂層の上層で大きく除去され,そ の除去率は $82 \%$ となったが, 60 週経過後も $5000 \mathrm{mg} / 1$ 程度の C O D が残存して流出することがわかった. 窒素の 除去率は $2 \%$ 以下で小さいものであったが,りんについては67\%の除去率が得られた.

\section{Key Words : leachate, landfill, land treatment, anaerobic digestion}

\section{1.はじめに}

廃棄物の排出量は年とともに増加の傾向にあり， それらの多くは最終的に廃棄物最終処分場に埋立て られる.この埋立処分場からは, 環境污染の一因と なっている浸出水と分解ガスが長期間にわたって発 生することが知られており，それらに関して質的， 量的な面からの種々の研究が精力的になされている.

一般廃棄物の最終処分場や産業廃棄物の管理型最終 処分場においては，遮水工を施し，地下への浸出水の 浸透を防いでいるが，この遮水工の劣化や穿孔などに よる損壊は無視できず" ${ }^{1)}$ ，そのための環境污染が報告 されている2).さらには, 廃棄物の不法投棄などの事 例も增加しており，不適切な処分による土歵・地下水 污染か懸念されている ${ }^{3)}$. 従って, これらの廃棄物か らの浸出水が土埣中に浸透する際の挙動を知ることは, 地下水污染や土壌污染の実態を知るために重要である.

また, 廃棄物の陸上埋立に際しては, 廃棄物の飛 散の防止, 圧縮除荷後の復元力の防止, 衛生害虫お よび臭気発生の防止，火災の防止などのために覆土 層を設ける4) . 覆土層の本来の目的としては以上の ようなものが挙げられるが,一方, この覆土層に， 廃棄物層からの浸出水が浸透すると, その濃度が低 下することから, 覆土層にはある程度の浄化作用が あることが報告されている(5) 11) 。従って, 廃棄物 の埋立処分場から発生する浸出水の水質や分解ガス を評価するためには, 単に廃棄物層内での変化のみ を考察するだけではなく, 覆土層の働きを併せて考 虑する必要があると考えられる. しかしながら, 廃 棄物埋立地浸出水のような, 高濃度の浸出水が土壤 に浸透した場合の挙動について, 詳しく検討された
例9)，10) は少ない。

土壌での浄化は，一般的に物理的浄化（漟過）, 物理化学的浄化 (吸着, 不溶化), 生物化学的浄化 (生物分解) などの作用によると考えられる ${ }^{12)}$.こ れまでにも，土壊の浄化能力を利用した排水処理の 研究が広く行われてきている.しかしながら，これ らの研究では, 主として濃度の低い二次処理水の浄 化を対象としており，さらに，脱窒による窒素除去 などの研究 ${ }^{13)}$ を除けば, 大部分は好気的な土㙥環境 下において検討されているにすきない。そこで，本 研究は,これまでにあまり検討されていない, 高濃 度の有機性廃液を対象とし，これが土壤に浸透し嫌 気的な環境に置かれた場合の挙動を知る第一段階と して, 土壤中における飽和浸透過程における高濃度 有機性廃液の微生物分解を中心とした物質変化を考 察することを目的としている.

本実験では，土壌のなかでもその組成が単純な砂 を充填したカラムを用いて，その挙動を考察した. また，カラム実験に際しては，これまで報告された ように廃棄物層を土壌層の上において，そこから溶 出する浸出水が土壌層に浸透するような方法 ${ }^{51}$ ，7) と はせず，砂力ラムに直接高濃度有機性廃液を注入す る方式とした。これは廃棄物層からの溶出過程が複 雑なことと，その濃度と組成が時間の経過とともに

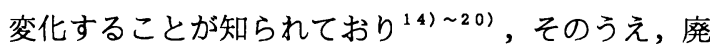
棄物層もある程度の浄化の場となっていることなど

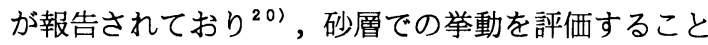
が難しくなるためである.

浸透の形態には，飽和流と不飽和流の場合があるが， 容易に嫌気的な条件にするためと,解析を簡単にする ために，砂層に流入した流入水の流れは，館和流で 


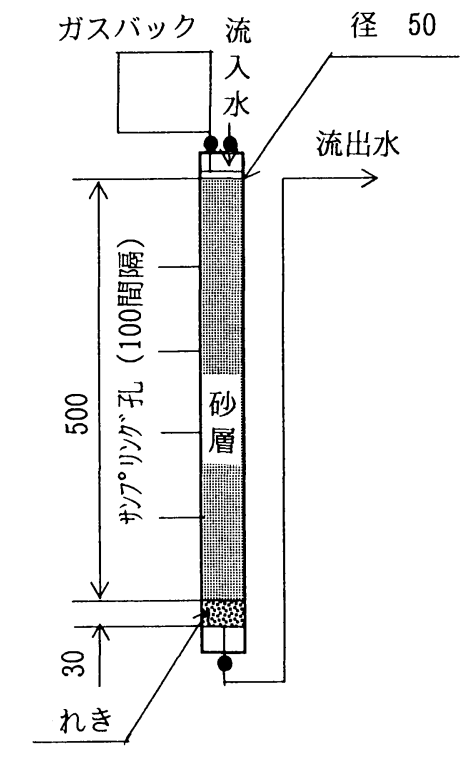

図-1 実験装置 (単位 $\mathrm{mm}$ )

浸透する方式とし, 主として有機物と窒素, りんに ついての挙動を対象に考察した.

\section{2. 実験方法}

\section{(1) 実験の概要}

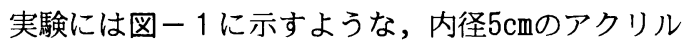
製円筒カラムを用いた。これに砂 $1.65 \mathrm{~kg} を 50 \mathrm{~cm}$ 高 さに詰め，その下に水抜けが良好になるように，90g のれきを厚さ $3 \mathrm{cml}$ にるように設け, カラムの両端を シリコン栓で密封した. 覆土層の厚さは, 覆土の目的, 埋立処分する廃棄物の種類と形状, 覆土材の種類, 周 辺環境条件等に応じて適切なものとしなければならな いと規定されているが, 埋立後に浸出水が浸透する即 日覆土や中間覆土はおおよそ $50 \mathrm{~cm}$ 程度であるので ${ }^{21)} こ$ れを参考にしてカラムの砂層厚を決定した. 砂の充填 に際しては, 間隙が蔗留水で飽和状態になるように して行った. カラム上端のシリコン栓には, カラム 流入水の流入用コックとガスバック取り付け用のコ ックが設置してあり, 下端のシリコン栓にはカラム 流出水用のコックが設置してある. また, 砂層内の 浸透水を採水するために10cm間隔にカラム側壁にサ ンプリング孔を設けた.

カラム流入水の流入コックと, カラム流出水コッ クはカラムへの流入と流出の際にのみ開けておき, 上部よりカラム流入水を流入させ, 下部より流出さ せた. その際, 流出水は砂の表面と同じレベルから 流出させるようにし, 流れは飽和流となるようにし
表 - 1 砂の物理・化学的性質

\begin{tabular}{lll}
\hline 比重 & 2.61 & \\
均等係数 & 2.63 & \\
有効径 & $0.38 \quad(\mathrm{~mm})$ \\
$\mathrm{C}$ & 0.228 & $(\mathrm{mg} / \mathrm{g})$ \\
$\mathrm{N}$ & 0.064 & $(\mathrm{mg} / \mathrm{g})$ \\
$\mathrm{C} \mathrm{O} \mathrm{D}$ & 0.271 & $(\mathrm{mg} / \mathrm{g})$ \\
強熱減量 & 5.0 & $(\mathrm{mg} / \mathrm{g})$ \\
$\mathrm{p} \mathrm{H}\left(\mathrm{H}_{2} 0\right)$ & 6.98 & \\
$\mathrm{p} \mathrm{H}(\mathrm{KCl})$ & 6.45 & \\
$\mathrm{CEC}$ & 4.7 & $(\mathrm{me} / 100 \mathrm{~g})$ \\
\hline
\end{tabular}

表 -2 流入水平均濃度

\begin{tabular}{lcl}
\hline $\mathrm{pH}$ & 11.9 & \\
$\mathrm{EC}$ & 7.62 & $(\mathrm{mS} / \mathrm{cm})$ \\
$\mathrm{SS}$ & 269 & $(\mathrm{mg} / \mathrm{l})$ \\
$\mathrm{COD}$ & 24700 & $(\mathrm{mg} / \mathrm{l})$ \\
$\mathrm{TOC}$ & 9360 & $(\mathrm{mg} / \mathrm{l})$ \\
$\mathrm{Cl}$ & 1270 & $(\mathrm{mg} / \mathrm{l})$ \\
$\mathrm{T}-\mathrm{N}$ & 2110 & $(\mathrm{mg} / \mathrm{l})$ \\
$\mathrm{T}-\mathrm{P}$ & 23.8 & $(\mathrm{mg} / \mathrm{l})$ \\
P功度 & 5970 & $(\mathrm{mg} / \mathrm{l})$ \\
炭水化物 & 553 & $(\mathrm{mg} / \mathrm{l})$ \\
蛋白質 & 12500 & $(\mathrm{mg} / \mathrm{l})$ \\
有機酸 & 903 & $(\mathrm{mg} / \mathrm{l})$ \\
\hline
\end{tabular}

た。しかしながら，後に述べるように，砂層内では 微生物による有機物の分解にともなうガスが発生し, 結果的には徐々に不飽和状態となった.

カラム流入水は一週間に一度，60mlを間久的に流 入させた.これは 1 年に換算すると $1590 \mathrm{~mm}$ （一週当 り $30.6 \mathrm{~mm}$ ）の流入負荷に相当し，日本のおおよその 年間降雨量に見合うだけの浸透量で砂層に流入する ことを想定している．埋立地からの浸出水量は, 蒸発 や表面流出があるために，その浸出率は一般に降雨量 の0.3〜0.4程度であると報告されている ${ }^{22)}$. しかし， 本実験では, 起こりうる最大の負荷量で流入すること を想定し，日本のおおよその年間降雨量に見合うだけ の流入水が砂層に浸透するものとして流入水量の条件 を定めた。なお, 実験は $20^{\circ} \mathrm{C}$ の恒温室内で 60 週にわ たって行った.

\section{（2）充填した砂とカラム流入水}

実験に供した砂は水道水で十分に洗浄し，付着物 を洗い流した川砂である.この砂の物理・化学的特 性を表一1に示す. カラムに充填した際の間隙率は 35.5\%であった.

カラムへの流入水は, 仙台市中心部の下水を処理 している終末処理場の脱水污泥ケーキを用いて作製 


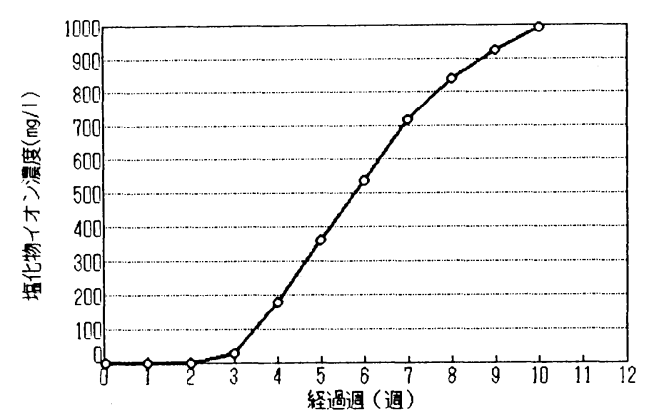

図-2 力ラムの流下特性

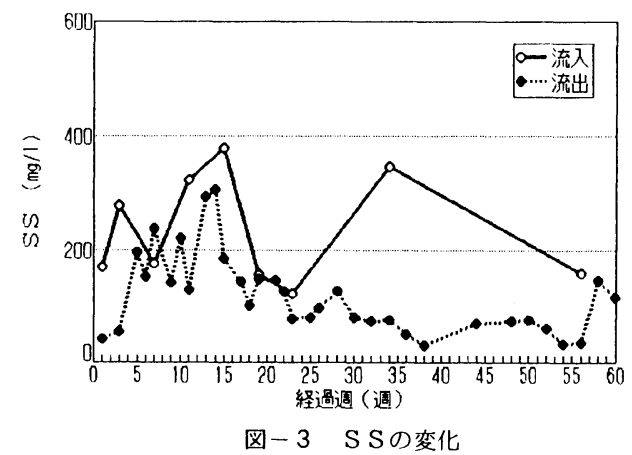

\section{3.結果および考察}

\section{（1）流下特性の検討}

カラム実験に先立ち, カラムの流下特性を把握す るために，実験に用いたものとまったく同じ条件の 砂力ラムを用い, カラム実験と同じ流入速度で 1000 mg/1の塩化物イオンを流入させ, その破過曲線を求 めた。この結果を図ー 2 に示す. 蒸留水で飽和状態 にある砂カラムに塩化物イオンを供給すると，3週目 から流出水の塩化物イオン濃度は増加し，10週目に 流入水とほぼ同じ濃度まで上昇することがわかった。 また, 間隙率 $35.5 \%$ から求めた間隙の体積 (348.3ml) と流入速度 (60ml/週) から, 平均滞留時間を計算す ると 5.8 週となった。この破過曲線の形は, 間久流入 にもかかわらず, 一定濃度の溶液の連続注入時に観 測されるものに類似しており，ポアボリュームが 1 に相当する滞留時間5.8週で, ほぼ流入水濃度の半分 の值を示した $\left.{ }^{25)}, 26\right)$. 砂層の間隙は蒸留水で満たさ れている状態から実験を開始したので，初期のカラ 么流出水は蒸留水で希釈されたものが流出する. 以 上の結果より，10週目までのカラム流出水は, 間隙 に存在する蒸留水による希釈の影響が現れることに なる。

\section{（2）カラム流出水の変化}

\section{a ) S Sの変化}

S S の変化を図ー 3 に示す. カラム流入水は, 冷 蔵庫に保存中にそのS S 成分はフロック化する傾向 にあったので, カラム流入水の S S 濃度の変動は大 きいが, 全実験期間を通じての平均濃度は269mg/1で あった. カラム流出水の S S 濃度は流入水の S S 濃 度よりも小さく, 14週まで増加し, その後減少する 傾向にあり，50〜60週の平均流出濃度は78mg/1で， 除去率は71\%であった。他の水質項目の流入水濃度に 比較すると流入水 S S 濃度は小さく, 各水質項目に 占めるS S 性成分の割合は小さいと判断されるので, このカラム実験では, 各水質項目の砂層内での濾過 


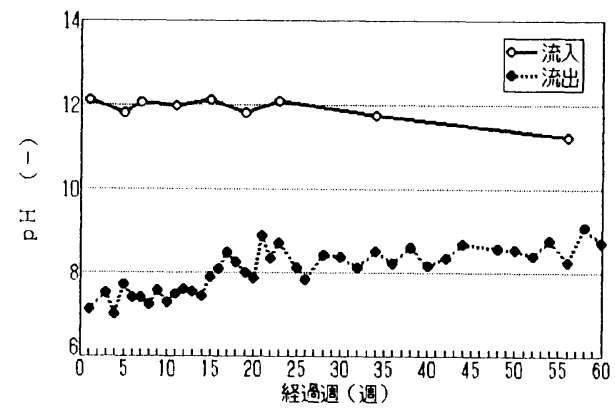

図-4 p Hの変化

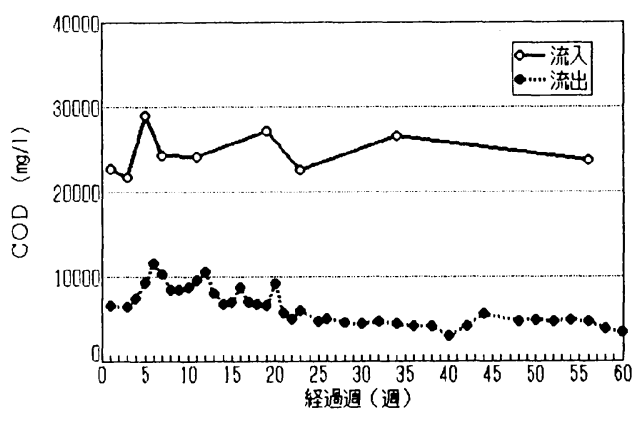

図-5CODの変化

作用による除去はそれほど大きくないものと考えら れる.

b ) $\mathrm{pH}$ 変化

図一 4 に p H 経時変化を示す. カラム流入水は, 脱水の際に消石灰を加えてある脱水污泥ケーキを用 いて作製したものであるために,その平均 $\mathrm{p} \mathrm{H}$ であり, 高い值を示している.一方, 流出水 $\mathrm{p} \mathrm{H}$ は 実験初期からこの值よりかなり小さい值で流出して おり, p H7から徐々に増加傾向にあり，50〜60週の 平均値は8.65であった。

\section{c) 有機物の変化}

$\mathrm{COD}$ の変化を図ー 5 に, T Cと T O Cの変化を図 -6 に示す. カラム流入水の平均 C O D 濃度は 24700 mg/lであった. カラム流出水の C O D は6週目で最大 值となり, それ以降は徐々に減少したが,約 $5000 \mathrm{mg} / 1$ 程度の濃度まで低下すると，実験期間が60週となっ てもそれ以下には減少せず, 最終的に流出水中にC ODが残存してしまう結果となった. また50〜60週 の平均 $\mathrm{COD}$ 除去率は $82 \%$ であった. $\mathrm{T} O \mathrm{C}$ も $\mathrm{COD}$ と同様の傾向で変化しており, カラム流入水の平均 $\mathrm{T} ＼textrm{O C}$ 濃度は9360mg/1であったが, カラム流出水の $\mathrm{T} O \mathrm{C}$ は6週目で最大值となり, それ以降は徐々に減 少した。しかし, 約 $1500 \mathrm{mg} / 1$ 程度の濃度まで低下す ると, 実験期間が経過してもそれ以下には減少せず, 50〜60週の平均 $\mathrm{T} O \mathrm{C}$ 除去率は $84 \%$ であった。また， 有機物の無機化にともなってI C が増加し, その濃 度は1500mg/1ほどになった。

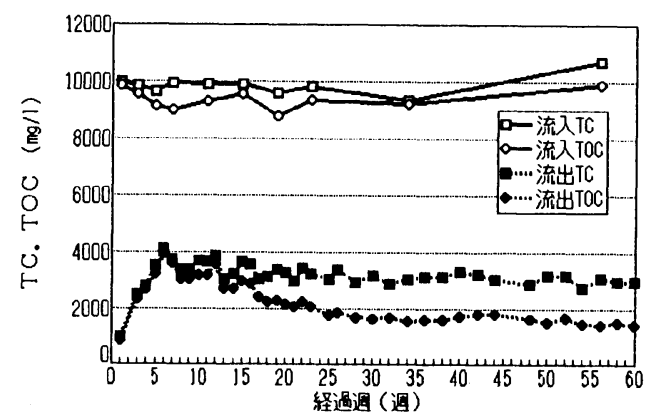

図-6 $\mathrm{TC}, \mathrm{TOC}$ の変化

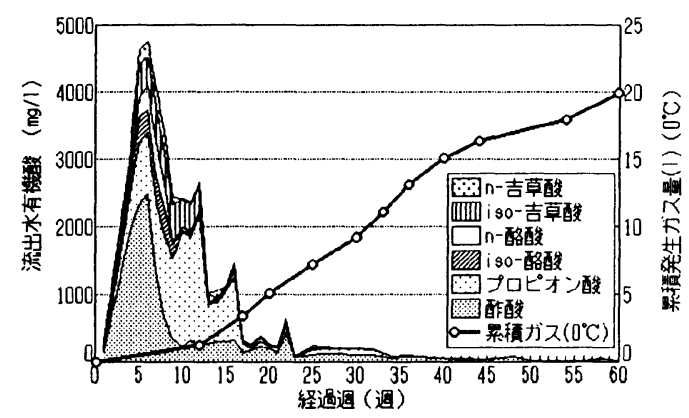

図-7 有機酸と累積発生ガス量の変化

S.Soyupac等") の実験では, 厚さ $41 \mathrm{~cm}$ のルト質砂 を充填したカラムで, $5700 \mathrm{mg} / 1$ の流入 C O D は90\%除 去されたと報告している. また，相坂等 ${ }^{7)}$ の行った カラム実験によるとCODの累積浸出負荷量は, 埋 立処分場で採取した残土の滤材層を設けると $50 \%$ ほど 減少すると述べており, 西村等 ${ }^{8)}$ も厚さ $25 \mathrm{~cm}$ の真砂 土の覆土層で $\mathrm{T} O \mathrm{C}$ が約 $10000 \mathrm{mg} / \mathrm{l}$ から約 $4000 \mathrm{mg} / \mathrm{l}$ ま で顕著に低下していることを報告している．このよ うに，有機物は数 $10 \mathrm{~cm}$ の土壌層を通過する間にかな りの大きさで減少することがわかる.

有機酸と累積発生ガス量の変化を図ー7に示す. 有機酸は, 酢酸, プロピオン酸, n-酪酸, iso-酪酸, $\mathrm{n}$-吉草酸, iso-吉草酸の6種類について分析し，有機 酸濃度はそれらの合計濃度で表した. 流入水の平均 有機酸濃度は903mg/1であったが, カラム流出水の有 機酸濃度は，6週目で最大の $4750 \mathrm{mg} / 1$ となり，その後 急激に減少し40週を過ぎてからは,70mg/1以下の濃度 しか検出されなくなった。8週までは酰酸が，9週目 以降はプロピオン酸が大きな濃度を示していた。

有機酸の濃度の減少に伴って, ガスの発生が観測

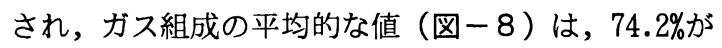
メタンであり，13.7\%が炭酸ガスであった．後に述べ るように, カラム流入水には蛋白質が高濃度で含ま れていた．蛋白質の嫌気的な分解によってメタン $71 \%$ ， 炭酸ガス $29 \%$ 含む分解ガスが発生し，炭水化物や有 機性脂肪よりも，蛋白質の分解にともなうメタンの 含有量が大きいことが報告されている ${ }^{27)}$. また嫌気 


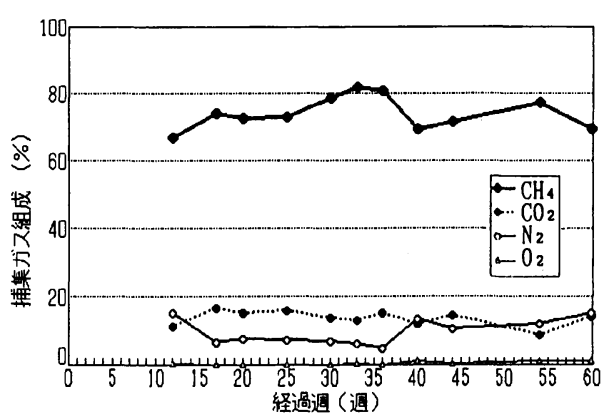

図-8 捕集ガス組成の変化

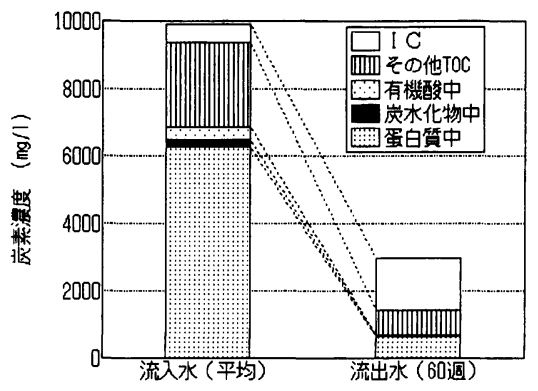

図－9 流入水と流出水の炭素濃度の構成

性消化での発生ガスの主成分はメタンで，67〜 75\%を 占め, 炭酸ガスがこれについで25〜35\%を占めている と述べられている ${ }^{28)}$. 本実験でのメタン含有率はこ れらに相当する大きさであったが, 炭酸ガス量はこ れらよりも小さい値を示した.

累積発生ガス量はほぼ直線的に増加していたので， 12〜60週の期間における勾配より平均的な発生ガス 速度を求めると, $403 \mathrm{ml} /$ 週 $\left(0^{\circ} \mathrm{C}\right.$ 換算) となった. 発 生ガス中に移行したメタンの C O D 換算值を発生ガ ス速度, メタン含有量, CODへの換算係数 (2.857 $\left.\mathrm{mg}-\mathrm{COD} / \mathrm{ml}-\mathrm{C} \mathrm{H}_{4}\right)^{29)}$ から求めると $854 \mathrm{mg} \mathrm{C} \mathrm{O} \mathrm{D} \mathrm{/}$ 週となり, カラムへの週当りの C O D 流入負荷に対 する比率は $57.6 \%$ となった.

平均流入水と流出水 (60週) についての炭素の構 成を図ー9に示す. それぞれの有機物中の炭素含有 量は, 蛋白質については $50 \%$, 炭水化物については40\% とし, 有機酸についてはその分子式より炭素含有量 を求め算出した. 炭素の構成から有機物の分解を考 察すると, 流入水の有機性炭素の $67 \%$ が蛋白質中に含 まれるものであり, 流出水ではこれが $1 / 10 に$ 減少し ており，この蛋白質の分解が有機物の減少に大きく 寄与していることがわかる. また, 有機物の分解に ともない流出水中の I C は増加し, 流入水の2.8倍に 達していることがわかった。

以上の結果から，24700mg/1のCOD が砂層に浸透 すると，COD除去率は82\%になったが，60週経過し ても, 5000mg/1のCODが残存して流出してしまう

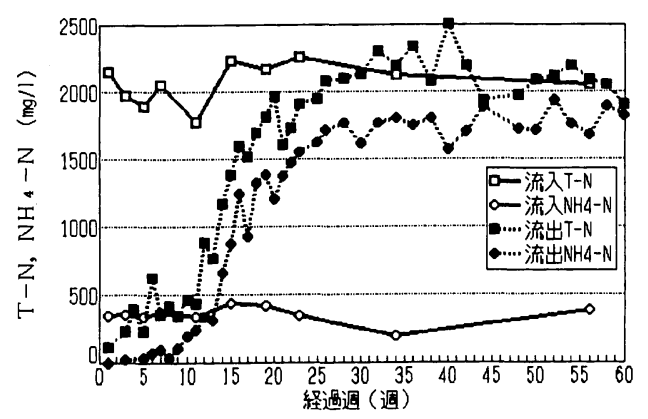

図-10 $\mathrm{T}-\mathrm{N}, \mathrm{NH}_{4}-\mathrm{N}$ 変化

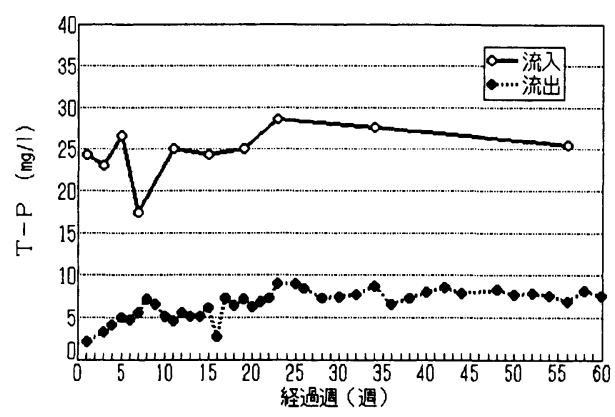

図-11 T-Pの変化

結果となった。また，CODの減少には，蛋白質の 分解が大きく寄与しており，除去 CODの57.6\%がメ タンガスとして捕集された。

d) 窒素, りんの変化

$\mathrm{T}-\mathrm{N}^{2} \mathrm{NH}_{4}-\mathrm{N}$ の変化を図ー 10 に示す. 流入 水の平均 $\mathrm{T}-\mathrm{N}$ 濃度は $2110 \mathrm{mg} / \mathrm{l}$ であり, 平均 $\mathrm{N} \mathrm{H}_{4}$ $\mathrm{N}$ 濃度は358mg/lであった。流入水には $\mathrm{N} \mathrm{O}_{2-} \mathrm{N}$, $\mathrm{NO}_{3}-\mathrm{N}$ はほとんど含まれていなかったので, 流入 水の $\mathrm{T}-\mathrm{N}$ は, $\mathrm{NH}_{4}-\mathrm{N}$ と有機態窒素で構成されて いる. $\mathrm{T}-\mathrm{N}$ と $\mathrm{N} \mathrm{H}_{4}-\mathrm{N}$ の経時変化より, 時間の経 過にともなって，有機態窒素が $\mathrm{N} \mathrm{H}_{4}-\mathrm{N}$ に分解し， 流出 $\mathrm{T}$ - $\mathrm{N}$ のほとんどを $\mathrm{N} \mathrm{H}_{4}-\mathrm{N}$ が占めていること がわかる. 50〜 60週の流出水の平均 $\mathrm{N} \mathrm{H}_{4}-\mathrm{N}$ 濃度は $1810 \mathrm{mg} / 1$ であったので，およそ1450mg/1の増加とな る. 流入水には $12500 \mathrm{mg} / 1$ の蛋白質が含まれており， 60 週の流出水では $1330 \mathrm{mg} / \mathrm{l}$ まで減少していた. 蛋白 質の窒素含有量を $14 \%$ とすると，この蛋白質の分解に よって1560mg/1の N H 4 - Nが増加することとなり， $\mathrm{NH}_{4}$ - Nの増加の実測值とほぼ見合う量となってい る. 流出水の $\mathrm{T}-\mathrm{N}$ 濃度は30週頃までに流入水の $\mathrm{T}-\mathrm{N}$ と同じ濃度まで上昇し，ほとんど除去されな くなる結果となった. しかし，塩化物イオンの流出 特性と比較すると, $\mathrm{T}-\mathrm{N}$ の流出の遅れが見られる. これは，実験の初期に， $\mathrm{NH}_{4}-\mathrm{N}$ が砂に吸着される ためと考えられる(0).

カラム流入水と流出水の $\mathrm{T}-\mathrm{P}$ 濃度の変化を図一 11 に示す. 流入水の平均 $\mathrm{T}-\mathrm{P}$ 濃度は $23.8 \mathrm{mg} / 1$ で 


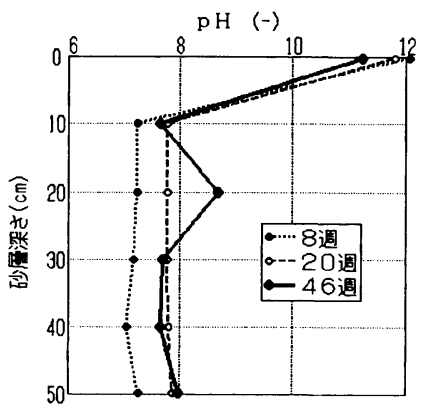

図-12 p Hの砂層内変化

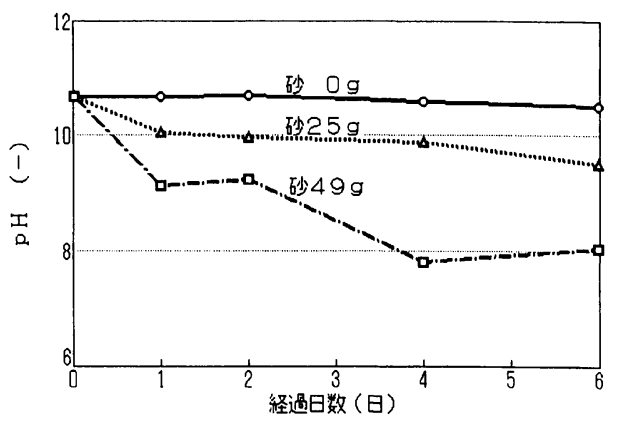

図ー13 砂による p Hの緩衝実験

あった. 流出水は7〜8mg/1で流出しており, 安定し て除去されている. 50〜60週の除去率は67.6\%であっ た.

\section{（３）砂層内での変化}

それぞれの水質項目について, 砂層内での変化を 知るために，10cm間隔に設けたサンプリング孔から 浸透水を採水し分析した。 なお，採水は流入水を力 ラムに流入させてから一週間経過後, その週の流入 の直前に行った.

\section{a ） pHの砂層内変化}

$\mathrm{pH}$ Hカラム内での変化を図ー 12 に示す.ここ で, 深さ $0 \mathrm{~cm}$ の值はカラム流入水の $\mathrm{p} \mathrm{H}$ を, $50 \mathrm{~cm}$ の值 はカラム流出水の值を示している. p H は深さ $10 \mathrm{~cm}$ まで大きく減少し, それよりも深いところでの変化 は小さかった.この p H の低下は, 土㙥の p H緩衝作 用 $\left.{ }^{301}, 31\right)$ や, 微生物分解による有機酸の生成 $\left.{ }^{7)}, 20\right)$, $\mathrm{CO}_{2}$ の溶解 $^{32)}$ などが影響しているものと考えられ る.

$\mathrm{p} \mathrm{H}$ の低下の一因と考えられる砂の $\mathrm{p} \mathrm{H}$ 緩衝能力 を確認するために, カラム実験に用いたものと同じ 砂に，カラム流入水を入れ，その $\mathrm{p} \mathrm{H}$ 変化を測定 するビーカーテストを行った。実験には容量の異な る3種類の試験管を用いた。この3種類の試験管は, 一 定量のカラム流入水 $(13 \mathrm{ml})$ と砂（それぞれ0,25,49g) を入れた場合に，ヘッドスペースができないように蓋

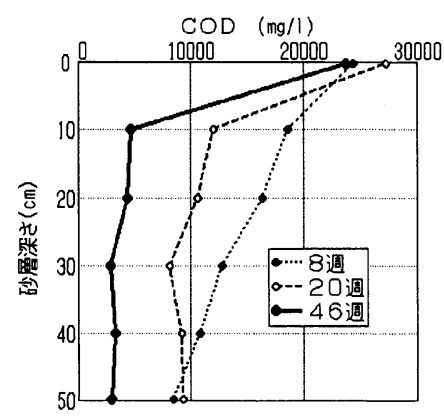

図-14 CODの砂層内変化

ができるような容量を持つものを特に選定したもので ある.ヘッドスペースができると，その中の空気中に 含まれる炭酸ガスの溶け込みによる p H の低下が生じ ると考えられるので，それを避けるためである．選定 した 3 種の試験管に $13 \mathrm{~m}$ lのカラム流入水を入れ, 更に 砂をそれぞれ0,25,49g入れて，ヘッドスペースがで きないように蓋をした． カラム流入水13mlに対して 49gの砂をゆるく詰めた場合, 砂はほぼカラム流入水 で飽和された状態となる．静置状態で試験管内の力 ラム流入水の $\mathrm{p} \mathrm{H}$ の経時変化を測定した．その結果 を図一１3に示す. 砂を入れていないカラム流入水 の p H 低下はほとんどなかったが，砂を入れたも のについては p H の低下が認められ, 砂の量が多い ほど著しく $\mathrm{p} \mathrm{H}$ が低下する結果となった。 砂の量が 49gの場合, 実験開始時の $\mathrm{p} \mathrm{H}$ 值10.9から, p Hは徐 々に減少し，4日で p H8程度まで減少していること がわかる．これらの結果から，pHの低下の一因と して, 砂による $\mathrm{p} \mathrm{H}$ の緩衝作用が働いているものと 考えることができる.

また京才等 ${ }^{5)}$ のカラム実験でも，p H は8以下の浸出水が砂層を通ると, $\mathrm{pH}$ ガ約 8 程度に なり,これは実験期間1000日まで持続していたと報 告されている.さらに, pH12の焼却灰溶出液を7〜 21 日の滞留日数で $30 \mathrm{~cm}$ 厚さの砂層を通すと $\mathrm{p} \mathrm{H}$ は7.0 〜 7.6となり中性化することが報告されている333). 一方, S. Soyupac等 ${ }^{9)}$ は, 土壌の働きとして, 有機酸 の生成によって酸性になるのを土袞が中性化し, メ タン菌の増殖を高める働きを述べている．このよう に土壤中での $\mathrm{p} \mathrm{H}$ の中性化が種々報告されており， これは微生物の土壌中での活性を維持するのに重要 な働きであると考えられる．pH緩衝作用の原因につ いては, イオン交換の働きや p H依存荷電の存在など が挙げられるが ${ }^{01}$, その機構については今後更に詳細 な検討が必要である.

\section{b ）有機物の砂層内変化}

カラム内での C O D 濃度の変化（図-14）は， 実験の初期の8週では, 上層から下層にかけて一様に 減少していたが, 実験期間が経過すると, 深さ $10 \mathrm{~cm}$ 

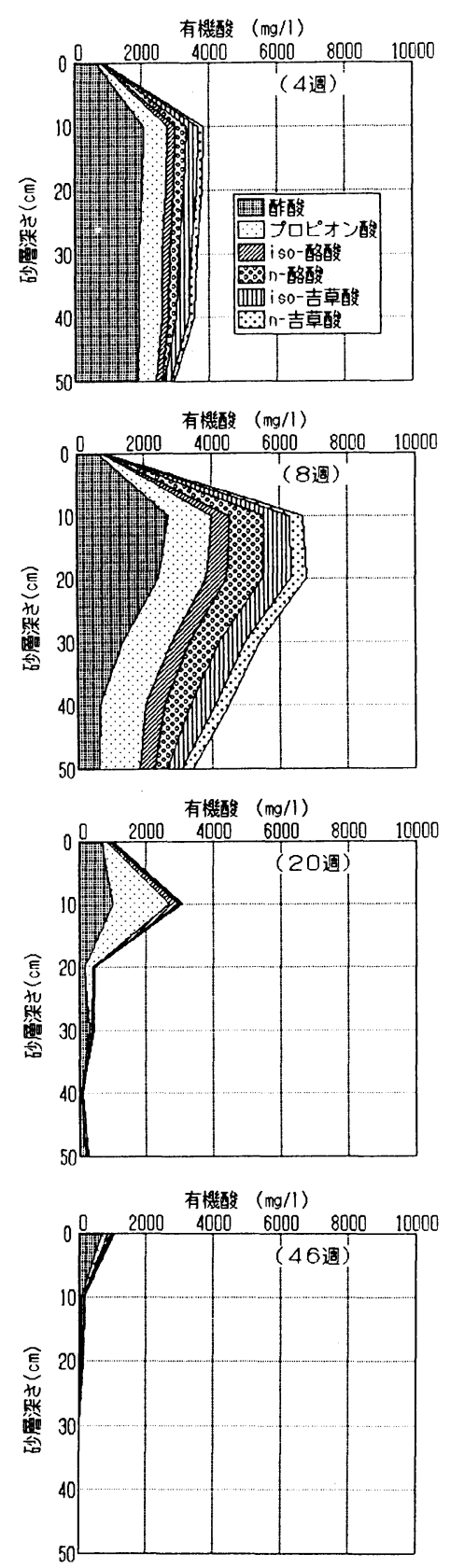

図-15 有機酸の砂層内変化

まで大きく減少し，それよりも深い層での変化は極 めて小さくなる傾向を示した.この結果より，実験 期間の経過にともなって, CODの分解速度が大き くなっていることと，CODの除去は，カラムに流

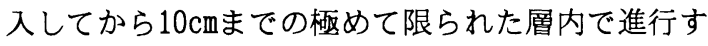
るようになることがわかった。この原因については， 時間の経過とともに砂層での C O D の分解速度が増 加し, カラムへの流入は週に一度の間欠流入である ので，流入してから次の流入があるまでの間に，易

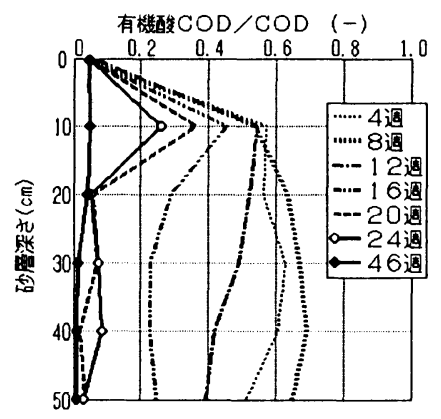

図-16 有機酸 COD/COD の砂層内変化

分解性のものがカラムの上層で分解してしまい, 難 分解性のものだけが残存してしまうものと考えられ る.

カラム内での有機酸濃度の変化（図－15) は, 4週目の $10 \mathrm{~cm}$ におる深さで $3850 \mathrm{mg} / 1$ となっており， 8 週目では, $10 \mathrm{~cm}$ 深さで $6730 \mathrm{mg} / 1$ まで増加してい る. 20週では全層にわたって大きく減少しており， 46週では更に減少して，砂層の半分より深い層では ほとんど検出されていない，CODと有機酸の砂層 内変化を考え合わせると，実験期間が経過すると上 部10cmまでで有機酸の生成とガス化が活発に進み， CODが大きく除去されることがわかる.

$\mathrm{C} O \mathrm{D}$ 濃度に寄与する有機酸濃度の大きさの変化 を知るために，有機酸を CODに換算したもの ${ }^{291}$ （有機酸 COD）と COD との比を求めたものを図

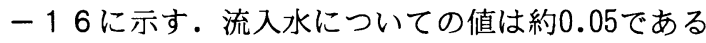
が，4週目では10cmの深さで0.6ほどになり，それよ り深い層ではほとんど変化しておらず，流入した有 機物の一部が上層部で有機酸へ分解し,下層部では大 きな変化はなくそのままの比で流出していることが わかる. 16週目以降, この比は10cmまでは増加する がそれよりも深い層では減少する傾向が見られ，46 週目では全層で小さくなっていることがわかる.こ の結果，実験初期から12週までは，深さ10cmまでに 有機酸 C O D の占める割合は0.4以上の值を示すよう になり,それより深い層でもこの值を維持しており， C ODに占める有機酸の寄与が大きいことが示され た.その後, 有機酸の比は減少し, その寄与は次第 に小さくなっていくことがわかった.

c）窒素, りんの砂層内変化

$\mathrm{T}-\mathrm{N}$ と $\mathrm{NH}_{4}-\mathrm{N}$ の砂層内変化を図 $-17,18$ に示す. $\mathrm{NH}_{4}-\mathrm{N}$ の砂層内での変化は, 8 週目で10 cmの深さで $810 \mathrm{mg} / 1$ の濃度となっており，20週目以降 では, $10 \mathrm{~cm}$ 深さで流出水と同程度の濃度まで増加 しており，10cmまでの変化が大きいことがわかる． 一方, 20 週目以降の $\mathrm{T}-\mathrm{N}$ の砂層内での変化につい ては，変動が多少あるものの，流入水と流出水は同 


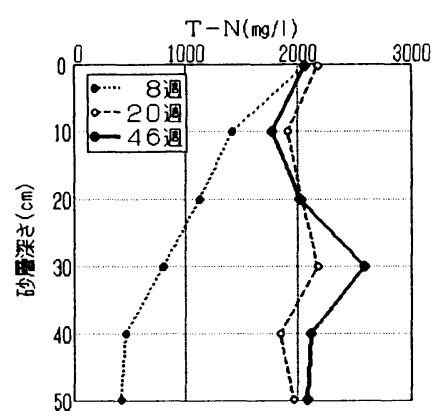

図-17 T-Nの砂層内変化

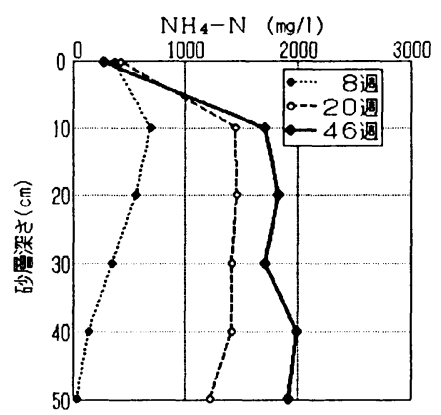

园-18 $\mathrm{NH}_{4}-\mathrm{N}$ の砂層内変化

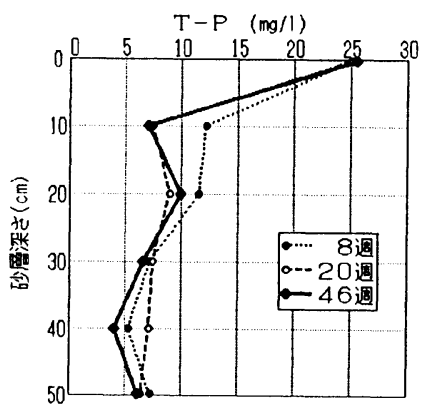

図-19 $\mathrm{T}$ - $\mathrm{P}$ の砂層内変化

程度の濃度となり，砂層ではほとんど除去されてい ないことがわかる.

$\mathrm{T}$ - $\mathrm{P}$ の砂層内での変化（図－19）は，10cmま で流下する間に大きく減少し，それより深い層では 大きな変化がなく, 砂層の上䅉部で大きく除去され ていることがわかった．土壌浸透処理においてりんの 除去率は高く，これらは吸着作用やアルミニウム，鉄， カルシウムなどと化学的に結合して不溶化し水系から 除去されることが知られており ${ }^{12)}$ ，本実験においても これらの作用によって除去されたものと考えられる.

\section{（4）砂への付着物質の変化}

カラム実験期間は60週であったが，この期間内に目 詰まりは生じなかった. 実験期間の経過にともなって， 砂層の表面に薄い膜が形成され，砂層の表面から10 $15 \mathrm{~cm}$ にかけて黒く変色するのがみられた。 カラム実験

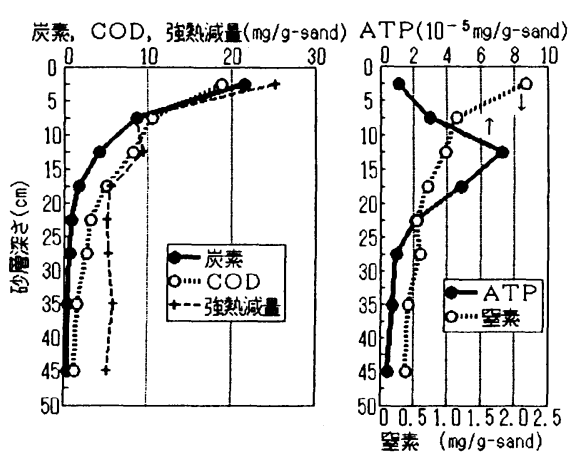

図-20 砂への付着物の変化

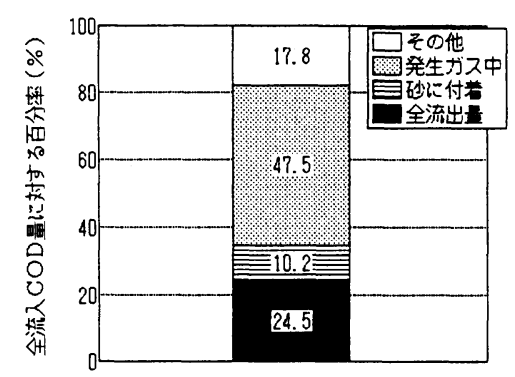

図-21 C O D収支

終了後, 深さ $30 \mathrm{~cm} ま て ゙ は 5 \mathrm{~cm}$ 間隔に，それより深い層 では $10 \mathrm{~cm}$ 間隔でカラム内の砂を取り出した. その後, 直ちに砂への付着生物量とその活性を評価する目的 で，A T Pを測定した ${ }^{34)}$ ．さらに，砂に付着してい る炭素, COD, 強熱減量, 窒素を測定した。これ らの結果を図ー 20 に示す. 炭素, COD, 強熱減 量, 窒素はいずれも上層で大きく, 下層ほど小さく なる傾向にあった．しかし A T Pは，10〜15cmでピ 一クを持つ変化を示し, 他の成分とは異なる砂層内 分布を示した.これは, 間欠流入のために表層では 負荷の変動が大きいこと, p Hの大きい流入水に曝 されることなどが原因であると考えられる．AT P が小さい上層の区間で C O D の除去が大きく進行する 原因について考察すると，カラム流入水は間欠的に上 層から流入しており，流入水は上層に滞留することに なる. 従って,上層での C O D 分解能力がそれほど大き くなくとも次の流入までに上層に滞留している易分解 性のCODの分解が進むことなどが考えられる。

\section{(5) COD収支}

全実験期間における C O D 収支を以下のように計 算し検討した。

(1)全流入 COD 量 $=\Sigma(\mathrm{C}$ in $\times \mathrm{Q}$ in $)$

(2)全流出 $\mathrm{COD}$ 量 $=\Sigma(\operatorname{Ceff} \times$ Qeff $)$

$\mathrm{C}$ in : 流入水 $\mathrm{COD}$ 濃度 $(\mathrm{mg} / \mathrm{l})$

$\mathrm{Q}$ in : 流入水量 (1) 
Ceff : 流出水 C O D 濃度 $(\mathrm{mg} / \mathrm{l})$

Qeff : 流出水量 (1)

(3)砂への付着 COD量

$=\Sigma((\mathrm{CODi}-\mathrm{COD} 0) \times \mathrm{Wi})$

CODi : それぞれの深さにおける

付着 COD量 $(\mathrm{mg} / \mathrm{g})$

C O D 0 : カラム実験開始時の付着 $\mathrm{COD}$ 量 $(\mathrm{mg} / \mathrm{g})$

Wi : それぞれの深さにおける砂 の重量 $(\mathrm{g})$

(4)発生ガス中 C O D 量は図ー7に示した発生ガス 中のメタンの体積をその組成から求め, 係数 $2.857 \mathrm{mg}$ $-\mathrm{COD} / \mathrm{ml}-\mathrm{C} \mathrm{H}_{4}{ }^{29)}$ を乗じて求めた.

これらの計算結果を図ー2 1 に示す. 全流入 C O $\mathrm{D}$ 量(1)に対して, 全流出 COD量(2)が24.5\%, 砂へ の付着 C OD量(3)が $10.2 \%$, 発生ガス中 C O D 量(4) が47.5\%であり, 回収率は $82.2 \%$ あった. 未回収分 については，この実験では，カラム上端でのみガス を捕集したので, 流出水に混入して気泡状になって 出るガスがあり，発生した $\mathrm{C} \mathrm{H}_{4}$ をすべて回収できな かったこと, 除去された CODの一部が $\mathrm{C} \mathrm{H} 4$ 以外の 物質 $\left(\mathrm{H}_{2} \mathrm{~S}\right.$ など）に転換したこと $\left.{ }^{35}\right)$,流入水, 流出 水,そして砂に付着している成分に, COD分析の際の 酸化率に違いがある可能性があることなどが原因と考 えられる。

前述のように，土㙵での浄化は物理的浄化（濾過）， 物理化学的浄化 (吸着, 不溶化), 生物化学的浄化 （生物分解）などの作用によると考えられが，CO Dの収支の検討から， CODの減少には生物分解が 大きく寄与していることがわかった.

\section{4. おわりに}

廃棄物最終処分場における浸出水のように，高濃 度の有機物を含む廃液が覆土層や地下に浸透する場 合の挙動を知るために, 嫌気的な条件にある砂力ラ ムを用いた実験を行い検討した。 その結果次の点が 明らかになった。

(1)高濃度有機性廃液が50cmの砂層に浸透した場合， CODについては80\%以上の大きな除去率が得られた. また，CODは，砂層へ流入してから $10 \mathrm{~cm}$ の深さま での限られた区間で大きく除去され，それより深い 層ではほとんど変化していないことがわかった。こ の CODの除去には, 生物分解が大きく寄与してお り，その中でも流入水中の蛋白質の分解の影響が大 きいことが示された.しかし，一方では60週経過後も 除去されずに残存するＣＯＤ成分があることがわか った.
（2）ＣＯDの収支を検討したところ，全流入 C O D の 47.5\%がカラム上端に設置したガスバックに捕集され， 10.2\%が砂層に付着して除去され，24.5\%が流出した. (3)窒素成分については, 有機態窒素の $\mathrm{N} \mathrm{H}_{4}-\mathrm{N}$ へ の分解が生じているが, 砂層中での $\mathrm{T}-\mathrm{N}$ の除去率 は極めて小さく, 従って, 高濃度の $\mathrm{N} \mathrm{H}_{4}-\mathrm{N}$ が流出 する結果となった．また，有機態窒素の $\mathrm{NH}_{4}-\mathrm{N} へ$ の分解は砂層の上層部で生じていた.

(4)りんについては，67\%の除去率が得られ，この除 去は砂層の上層部で大きいことがわかった.

(5)カラム実験終了後, 砂への付着量を測定したとこ 了, 炭素, COD, 強熱減量, 窒素については, 上 層部で大きく，下層部で小さくなる傾向にあったが, A T Pについては, 10〜15cmの深さでピークをもつ 変化を示した。

以上の結果より, 廃棄物埋立地内の覆土層では有 機物は大きく除去されるが，一方では残存するもの があること, 窒素の除去は望めないが, りんの除去 は期待できることなどがわかった．今後は,降雨にと もなって発生量が変化する浸出水のように, 間欠的に 土壤層に流入する場合の流下特性や浄化機構をさら に明らかにすることと，不飽和状態で浸透する場合 や，浸透する廃液の水質の違いによる浄化特性の検 討を行うことを課題としたい.

\section{参考文献}

1）国松孝男, 菅原正孝: 都市の水環境の創造, 技報堂出 版, pp.238〜263, 1992.

2)花嶋正孝,松藤康司,島岡隆行,押方利郎：しゃ水シート の試験方法に関する一考察, 第 4 回廃棄物学会研究発表 会講演論文集 I, pp.495 498, 1993.

3）中杉修身: 土虽・地下水污染の現状と対策, 廃棄物学 会誌, 第5巻, 第2号,pp. 164 173, 1994 .

4）高橋一三：土㙵の污染と浄化作用（8）－廃棄物の埋 立 (その 1) 一, 水処理技術, Vol.15, No.2, pp.1 $\sim 17,1974$.

5）京才俊則, 大嶋吉雄, 岡久宏史 : 下水污泥の埋立に伴 う浸出水・余水の性状調查報告書, 土木研究所資料 第2322号, 1986年3月.

6) 京才俊則, 大嶋吉雄, 近藤次夫 : 浸出水 - 余水の処理 に関する調查, 土木研究所資料 昭和 60 年度下水道関 係調查研究年次報告集, 1986 .

7）相坂清子, 平間幸雄 : 下水污泥からの浸出成分につい て, 下水道協会誌, Vol.20, No.282, pp. 56 66, 1987 .

8）西村文緒, 島岡隆行, 花嶋正孝: 埋立地における硬化 型フォームの即日覆土材としての有効性について（そ の 2), 廃棄物学会第 4 回研究発表会講演論文集 I, pp. 465 468, 1993.

9) Soyupac, S. , Farquhar, G. J. and Sykes, J. F. :Modelling 
Contaminant Attenuation in Soil: Microbial Decomposition of Organic Matter. In Land Disposal of Hazardous Wastes, EPA-600/9-78-016,pp.245 254, 1978.

10)Kjeldsen,P. and Christensen, T.H. : Soil Attenuation of Acid Phase Landfill Leachate, Waste Management \& Research,pp.247〜263,1984.

11)Loes, V.E.: Mineralization of organic matter in the subsoil of a waste disposal site, Soil Science, Vol.16, No.1,pp.22 28, 1978 .

12)国松孝男, 菅原正孝: 都市の水環境の創造, 技報堂出 版, pp.146〜166,1992.

13)山口登志子, 寺西康治 : 不飽和浸透流における脱窒過 程, 衛生工学研究論文集, 第23巻, pp. 211 217, 1987 .

14)Ehrig, H. J. : Quality and Quantity of Sanitary Landfill Leachate, Waste Management \& Research , Vol.1, pp. $53 \sim 68,1983$.

15)花嶋正孝, 松藤康司 : 埋立場からの浸出污水量とその 水質, 都市と廃棄物, Vol.8, No.8,pp.25〜32,1978.

16)水野勝, 溝口清数, 稲垣成房 : 産業廃棄物埋立地モデ ルの浸出水について（第 2 報），水処理技術，Vol.27， No. 3,pp. 57 63, 1986 .

17)水野勝, 溝口清数, 神谷正俊 : 産業廃棄物埋立地モデ ルの浸出水について（第 3 報），水処理技術，Vol.27， No. 5 , pp. 35 41, 1986 .

18) 水野勝, 溝口清数, 神谷正俊: 産業廃棄物埋立地モデ ルの浸出水について（第 4 報），水処理技術，Vol.27， No. 9, pp. 27〜31,1986.

19)田中信寿, 神山桂一：都市廃棄物嫌気性埋立層中の可 溶性污濁物生成過程に関する研究, 土木学会論文集, 第381号，II-7，pp.217〜225, 1987 .

20)李南勲, 楠田哲也, 島岡隆行, 松藤康司, 花嶋正孝 : 埋立 廃棄物層における污濁物質の質変換現象に関する実験 的研究, 廃棄物学会論文誌, Vol.4, No.2, pp.53〜 63, 1993.

21）（社）全国都市清掃会議 : 廃棄物最終処分場指針解
説, pp.226〜229, 1994.

22)花嶋正孝,松藤康司,樋口壮太郎, 堀内朝夫, 山本一郎, 島崎武志, 北村隆 : 廃棄物埋立場浸出污水の処理に ついて, 水処理技術, Vol.18, No.10,pp.51〜61.1977.

23)Nakayama,M. and Enari, K.: The degradation of highly concentrated organic waste water by the sand layer method, proceedings 5th I.A.W.Q Asian Regional Conference on Water Quality and Pollution Control,pp. 685 691, 1995.

24）（社）日本下水道協会 ; 下水試験方法（1984年版）

25)中野政詩 : 土の物質移動学, 東京大学出版会, pp.71〜 75,1991 .

26)地下水問題研究会編 : 地下水污染論一その基礎と応用 - : 共立出版, pp.192〜230,1992.

27)岩井重久, 申丘澈, 名取眞: 下・廃水污泥の処理, コロナ社, pp.16〜43,1981.

28)井出哲夫 : 水処理工学, 技報堂出版,pp. 373 376, 1993.

29)李玉友, 野池達也 : 嫌気性消化の酸生成相における余 剩活性污泥の分解特性, 水質污濁研究, 第10巻, 第12 号, pp.729 740, 1987.

30)岩田進牛 : 土のはなし, 大月書店, pp.161 166, 1986 . 31)久馬一剛: 新土袞学, 朝倉書店, pp. 86 93,1991.

32)松藤敏彦, 田中信寿, 宮脇健太郎, 阿部知子 : 焼却灰埋 立層浸出水 $\mathrm{p} \mathrm{H}$ の決定要因, 土木学会第 48 回年講, pp. 1152 1153, 1993 .

33 建設省土木研究所 : 昭和62年度下水道関係調查研究年 次報告書集，土木研究所資料第2654号，pp. 106 109, 1988年10月.

34)Chung, Y-C. and Neethling, J.B. : ATP as a measure of anaerobic sludge digester activity, Journal WPCF, Vol.60, No.1,pp.107〜112,1988.

35)李玉友, 野池達也 : 污泥の嫌気性消化における細菌群 の分布と物質分解特性一メタン生成菌とホモ酢酸生成 菌を中心として一，水質污濁研究，第12巻，第12号， pp. $771 \sim 780,1989$.

(1996.3.29 受付)

\section{THE DEGRADATION CHARACTERISTICS OF HIGHLY CONCENTRATED ORGANIC WASTE WATER BY THE SAND LAYER METHOD}

\section{Masatomo NAKAYAMA and Keijiro ENARI}

The purpose of this study is to consider experimentally the degradation characteristics of highly concentrated organic waste water using a sand column for 60 weeks. The influent COD of $24700 \mathrm{mg} / 1$ was reduced by $82 \%$ over the $50 \mathrm{~cm}$ sand column length. The COD reduction was achieved in the upper sand layer. The $\mathrm{T}-\mathrm{N}$ in the inflow water was almost not removed, and which removal rate was less than $2 \%$. The T-P concentration was reduced, the average removal rate was $67 \%$. 